DOI: 10.34015/2523-4552.2019.2.04

Удк 342.95 (477)

Hecmop H. B.,

кандидат юридичних наук,

здобувач Відкритого міжнародного

університету розвитку людини

«Україна»

\title{
СИСТЕМА АДМІНІСТРАТИВНИХ ЗАХОДІВ ГРОМАДСЬКОГО КОНТРОЛЮ ЗА СУДДЯМИ В УКРАЇНІ
}

У статті характеризується система різноманітних способів здійснення адміністративних процедур контролю суб'єктами громадянського суспільства, зокрема в рамках таких форм, як моніторинг (спостереження, аналіз) та експертиза. Зазначається, що досить часто один і той же спосіб контролю може кореспондуватися з множиною адміністративних процедур його здійснення. Автор доводить, що інші форми (перевірка, оцінювання, корегування персонального складу суддівського корпусу, органів суддівського врядування та суддівського самоврядування, керівництва суду та Державної судової адміністрації України, нормотворчість) адміністративно-правовому статусу суб'єктів громадського контролю не властиві.

Ключові слова: громадський контроль; суд; суддя; судова сфера; громадськість.

В статье характеризуется система различных способов осуществления административных процедур контроля субъектами гражданского общества, в частности в рамках таких форм как мониторинг (наблюдение, анализ) и экспертиза. Довольно часто один и тот же способ контроля может корреспондировать с множественным числом административных процедур его осуществления. Автор доказывает, что другие формы (проверка, оценка, корректировка персонального состава судейского корпуса, органов судейского управления и судейского самоуправления, руководства суда и Государственной судебной администрации Украины, нормотворчество) административноправовому статусу субъектов общественного контроля не свойственны.

Ключевые слова: общественный контроль; суд; судья; судебная сфера; общественность.

Постановка проблеми. Практичне втілення можливостей громадського контролю відбувається в конкретних адміністративних формах та процедурах владного впливу на суд і суддів в Україні. Фактично компетенція суб'єктів саме громад- ського контролю реалізується лише через призму таких форм контролю, як спостереження (моніторинг, аналіз) та експертиза; щодо інших форм (перевірка, оцінювання, корегування персонального складу суддівського корпусу, органів суддівського вряду- 
вання та суддівського самоврядування, керівництва суду та Державної судової адміністрації України, нормотворчість), то вони адміністративно-правовому статусу суб'єктів громадського контролю не властиві.

Стосовно таких адміністративних процедур контролю, як спостереження (моніторинг, аналіз), експертиза, то суб'єкти громадського контролю повноважні здійснювати: 1) спостереження за дотриманням закону суддями в професійній діяльності; 2) спостереження за дотриманням суддями й кандидатами на посаду судді кваліфікаційних та особистісних вимог до особи судді; 3) моніторинг оптимальності структури судоустрою, правового статусу судів, суддів, органів суддівського врядування та самоврядування; 4) аналітику дисциплінарної та кваліфікаційної практики органів суддівського врядування; 5) експертне оцінювання регуляторного законодавства (проектів) як спеціального об'єкта дослідження.

Зазначені адміністративні процедури контролю можуть здійснюватися на практиці досить широким колом різноманітних способів реалізації управлінських повноважень, при цьому досить часто один і той же спосіб контролю може кореспондуватися 3 множиною адміністративних процедур його здійснення.

Аналіз останніх досліджень та публікацій. Питання громадського контролю, заходів контрольнонаглядової діяльності громадськості, як правило, розглядається та вивчається науковцями в контексті органів виконавчої влади та місцевого самоврядування, правоохоронних інституцій (праці таких учених, як С. Ф. Денисюк, М. М. Іжа, П. І. Каб- лак, Ю. В. Ковбасюк, В. М. Кравчук, А. С. Крупник, С. М. Кушнір, О. М. Музичук, Т. В. Наливайко, Л. П. Рогатіна, О. В. Савченко, В. Л. Синчук, О. З. Хотинська-Нор та інших). Водночас щодо судової сфери грунтовних фахових досліджень після судової реформи 2016 року практично немає, чим обумовлена актуальність даної статті.

Постановка завдання. Метою статті $\epsilon$ визначення та характеристика системи адміністративних заходів громадського контролю за суддями в Україні.

Виклад основного матеріалу. Розглядаючи питання способів здійснення громадського контролю, вважаємо за потрібне акцентувати увагу на понятті інформації (матеріальних, електронних їі носіїв), документів та дій, які можуть щодо неї вчинятися окремими суб'єктами (отримання, аналіз, оприлюднення тощо). Узагалі, з нормативної точки зору, інформація - будь-які відомості та/або дані, які можуть бути збережені на матеріальних носіях або відображені в електронному вигляді, а документ - матеріальний носій, що містить інформацію, основними функціями якого $є$ її збереження та передавання в часі та просторі [1]. Звичайно, фактичні дані про діяльність органів суддівського врядування та самоврядування, суддів, ухвалені ними рішення (у тому числі в частині здійснення правосуддя), а так само дотримання суддями та кандидатами на суддівські вакансії правил суддівської етики та вимог доброчесності, інших норм законодавства $€$ вагомою інформацією, маркером, який ідентифікує поточний стан справ, рівень законності та верховенства права в судовій системі України. 
Ведучи мову про отримання інформації як спосіб здійснення адміністративних процедур контролю, необхідно зазначити об'єктивну залежність цього способу від поточної державної політики публічності, прозорості, транспарентності функціонування влади, роботи посадових (службових) осіб. По суті, державна політика в цьому випадку виявляється в трьох площинах: по-перше, в аспекті створення інформаційних ресурсів, наповнюваних інформацією про суд, суддів та їх діяльність; подруге, установлення імперативних зобов'язань для судді, кандидатів на його посаду оприлюднювати фактичні дані про власні доходи та видатки, повідомляти про виникнення та врегулювання конфлікту інтересів, тиск на суд, оприлюднювати судові рішення тощо, - фактично наповнювати даними інформаційні ресурси, доступ до яких відкрито державою третім особам. По-третє, шляхом створення нормативних передумов реалізації права доступу фізичних та юридичних осіб до публічної інформації.

Відповідно до Положення про набори даних, які підлягають оприлюдненню у формі відкритих даних, до їх переліку, зокрема, належить Єдиний державний реєстр юридичних осіб, фізичних осіб - підприємців та громадських формувань, Єдиний державний реєстр декларацій осіб, уповноважених на виконання функцій держави або місцевого самоврядування, Єдиний державний реєстр судових рішень [2]. Ключовим джерелом інформації для громадських активістів про матеріальний стан посадовців (кандидатів на посади) $\epsilon$ Єдиний державний реєстр декларацій осіб, уповноважених на виконан- ня функцій держави або місцевого самоврядування, заповнення яких випливає з вимог законодавства про корупцію. Згідно зі статтею 45 Закону України «Про запобігання корупції» службові особи, у тому числі судді, зобов'язані щороку до 1 квітня подавати шляхом заповнення на офіційному веб-сайті Національного агентства 3 питань запобігання корупції декларацію за минулий рік [3]. Невиконання (неналежне виконання) цього обов'язку особою, яка обіймає посаду судді, $є$ істотним дисциплінарним проступком, що може зумовити навіть звільнення.

Важливість відкритості функціонування владного механізму зумовила закріплення на рівні окремого закону процедури доступу до публічної інформації третіх осіб [4]. У контексті контрольно-наглядової діяльності практичний інтерес становлять, насамперед, акти локальної правотворчості органів суддівського врядування (Вищої ради правосуддя та її дисциплінарних палат; Вищої кваліфікаційної комісії суддів України) та самоврядування, а також фінансова інформація (обсяг бюджетних видатків на суд і суддів, розмір винагороди (заробітна плата, премії, різні доплати) суддів).

Цікавим способом отримання об'єктивної інформації про реальний стан справ у судовій сфері є проведення різних соціологічних опитувань - на предмет довіри до суду, незалежності та політичної нейтральності суддів, рівня задоволеності професійним рівнем здійснення правосуддя тощо. Хоча провести опитування, наприклад, на виході з конкретного суду може будь-який індивід чи група осіб, найбільшу суспільну вагу з огляду на обсяг репрезентати- 
вної вибірки (кількості опитаних осіб у всіх регіонах країни) мають відомі соціологічні служби (Київський міжнародний інститут соціології, Центр Разумкова, Фонд «Демократичні ініціативи» імені Ілька Кучеріва, Социс, Соціологічна група «Рейтинг» та інші).

Після інтелектуальної, розумової обробки отриманої інформації, у тому числі завдяки інноваційним технологіям та комп'ютерним алгоритмам, громадяни, представники громадських організацій формують власні висновки, результати аналітичної чи експертної роботи. Звичайно, накопичення певної інформації, висновків після іï обробки не $\epsilon$ самоціллю суб'єктів громадського контролю - відповідні висновки 3 підтверджувальними доказами оприлюднюються в безадресній площині або надсилаються конкретним адресатам для розгляду, оцінки та прийняття рішення по суті порушеного питання.

Крім Вищої ради правосуддя та Вищої кваліфікаційної комісії суддів України, результати (висновки) аналітичної експертної роботи можуть передаватися й іншим, конкретно визначеним адресатам. Наприклад, громадською радою при Раді суддів цій Раді суддів; фізичними та юридичними особами - органам досудового розслідування за підслідністю (Національне антикорупційне бюро, Державне бюро розслідувань, органи поліції і тощо) при поданні заяви про вчинення злочину; у загальному порядку звернення громадян.

Стосовно такої правомочності суб'єктів громадського контролю як подання звернень, то останнє в розумінні законодавця $є$ викладеною в усній чи письмовій формі пропозиці- єю (зауваженням), заявою (клопотанням), скаргою [5]. 32015 року новацією вітчизняного правового поля стало правове явище електронних петицій.

На відміну від випадків, коли адресат аналітичної (експертної) роботи чітко визначений, широко розповсюджено безадресне, для широкого загалу оприлюднення результатів подібної роботи та зібраної інформації. Так, інформаційне агентство «Укрінформ» оприлюднило результати Всеукраїнського опитування громадян щодо незалежності та підзвітності судової влади та сприйняття судової реформи, проведеного у вересні 2018 року компанією GfkUkraine 3 ініціативи Програми реформування сектору юстиції «Нове правосуддя» USAID. Опитування засвідчило, що за 2018 рік рівень довіри суспільства до судів зріс на $6 \%$ порівняно $312 \%$ довіри, які було зафіксовано за результатами аналогічних соціологічних замірів у 2017 році [6]. Тобто суспільство інформується про динаміку індексу підтримки суду в соціумі, позитивну тенденцію сприйняття громадянами судової реформи, очищення судової влади від непрофесійних, політично чи матеріально заангажованих елементів.

Очевидно, переглядати і скасовувати судові рішення громадськість не може, але моніторити судові piшення і давати оцінку за певними критеріями - цілком. Так, наприклад, у 2014 р. фахівцями Центру політико-правових реформ було підготовлено аналітичний огляд судової практики за 2010-2014 рр. у справах про обмеження права на мирні зібрання і сформульовано певні висновки та рекомендації [7, с. 13]. Іншим 
прикладом $€$ Аналітичний огляд представників низки громадських організацій (Центр політикоправових реформ, Фундація DEJURE та ВГО «Автомайдан») про проміжні результати кваліфікаційного оцінювання суддів, зокрема обгрунтованість рішень щодо підтвердження здатності здійснювати правосуддя, оперативність рішень Вищої ради правосуддя щодо звільнення суддів, які не пройшли кваліфікаційного оцінювання [8]. Тобто аналітичні висновки, матеріали судової (дисциплінарної) практики, поведінки судді в судовому процесі можуть готуватися не тільки Вищою радою правосуддя чи Верховним судом, а представниками громадських організацій та об'єднань. При цьому факультативність зроблених висновків для суду та суддів обумовлює більшою мірою їх інформаційне призначення, донесення певних даних, тенденцій правосуддя до громадян, які не мають можливості системно аналізувати процесуальні документи з Єдиного державного реєстру судових рішень.

Сучасні інформаційні технології, широкий доступ населення до Інтернету, активність соціальних мереж надзвичайно спрощують донесення певної інформації широкому загалу. Останніми роками з'явилася ціла низка спеціалізованих інтернетсайтів, які викладають суспільно важливу інформацію про суд та суддів, власну аналітику та розслідування або ж спрощують (роблять більш зручним та зрозумілим) доступ населення до відповідної інформації. Серед найбільш значущих за змістом та обсягом інформації є проекти громадських організацій «Том 14», «Канцелярська сотня», «Центр UA», «Центр демократії та верховенства права», незалежної журналістської агенції «Слідство.Інфо».

Після набрання чинності в березні 2015 року Законом України «Про забезпечення права на справедливий суд» статусу імперативного правила набула норма про можливість осіб, присутніх у залі судового засідання, представників засобів масової інформації проводити в залі судового засідання фотозйомку, відео- та аудіозапис з використанням портативних відео- й аудіотехнічних засобів без отримання окремого дозволу суду [9]. Подібні законодавчі новації сприяли започаткуванню та розвитку проекту «Відкритий суд» накопиченню сукупності матеріалів відеозйомок судових процесів, а також наданню правової оцінки судовим справам, професійному та етичному рівню суддів та інших учасників процесу. Зазначимо, що до цього проекту, який започатковувався як громадська ініціатива, з часом почали приєднуватися як партнери Верховний Суд та суди нижчих ланок, проект ЄС «Підтримка реформ у сфері юстиції в Україні», асоціації адвокатів, інші організації й установи.

Зазначені інформаційні ресурси передбачають можливості для власної аналітичної діяльності будьякого небайдужого до проблематики сфери правосуддя представника громадськості. Водночас широкий загал населення зазвичай не є активним у такій аналітично-пошуковій роботі, віддає перевагу перегляду вже консолідованої інформації з висновками, коментарями зацікавлених осіб. У цьому контексті високий ступінь суспільної зацікавленості та довіри демонструють такі проєкти (телевізійні програми), як «Наші 
гроші», «Наші гроші. Досудилися», «Наші гроші з Денисом Бігусом», «Підсумки дня», «Народне НАЗК», «Слідство.Інфо» та ряд інших. Звичайно, у подібних телевізійних проєктах завжди присутній суб'єктивний чинник в оцінці певних осіб, їх вчинків, явищ.

Висновки. Система різноманітних способів здійснення адміністративних процедур контролю (у рамках його форм - спостереження, аналізу) та експертизи становить сукупність заходів 3: 1) отримання інформації з відкритих або закритих джерел, за результатами соціологічних досліджень, особистих інтерв'ю (розмов, консультацій) зі сторонніми суб'єктами (у тому числі тими, що $є$ об'єктом контролю), журналістських розслідувань тощо; 2) інтелектуальна, розумова обробка отриманої інформації, зокрема завдяки інноваційним технологіям та комп'ютерним алгоритмам, з формуванням власних висновків, звітів, оглядів, інших форм вираження результатів аналітичної чи експертної роботи; 3) надсилання інформації (висновків, матеріалів) будь-яким зацікавленим суб'єктом до Вищої ради правосуддя в рамках процедури подання дисциплінарної скарги; 4) надсилання Громадською радою доброчесності Вищій кваліфікаційній комісії суддів негативного висновку щодо відповідності судді (кандидата на цю посаду) вимогам професійної етики та доброчесності для врахування в процесі кваліфікаційного оцінювання; надсилання інформації (висновків, матеріалів) фізичними та юридичними особами органам досудового розслідування за підслідністю (Національне антикорупційне бюро, Державне бюро розслідувань, органи поліції та інші) при поданні заяви про вчинення злочину; у загальному порядку звернення громадян; 5) створення та забезпечення функціонування спеціалізованих інтернет-сайтів, які спрощують (роблять більш зручним та зрозумілим) доступ населення до відповідної інформації про суд та суддів (проекти «Декларації», «Посіпаки», «Гарна хата», «Суддівська кров», «Ring» (Кільце), «Чесно. Фільтруй суд», «Відкритий суд» та подібні); 6) оприлюднення результатів аналітичної та експертної роботи (консолідованої інформації 3 висновками, коментарями зацікавлених осіб у засобах масової інформації, зокрема на телебаченні та в мережі Інтернет.

Зазначена система різноманітних способів здійснення адміністративних процедур контролю не передбачає обов'язкової етапності. Часто ці способи реалізуються паралельно та відособлено, водночас можливі взаємні зв'язки, обумовленість одного способу іншим тощо.

\section{Список використаних джерел}

1. Про інформацію: Закон України від 02.10.1992 р. № 2657-XII. Дата оновлення: 01.01.2017. URL: https://zakon.rada.gov.ua/laws/show/2657-12 (дата звернення: 11.06.2019).

2. Про затвердження Положення про набори даних, які підлягають оприлюдненню у формі відкритих даних: постанова Кабінету Міністрів України від 21.10.2015 p. № 835. URL: https://zakon.rada.gov.ua/laws/show/835-2015\%D0\%BF\#n12 (дата звернення: 11.06.2019). 
3. Про запобігання корупції: Закон України від 14.10.2014 р. № 1700-VII. URL: https://zakon.rada.gov.ua/laws/show/1700-18 (дата звернення: 11.06.2019).

4. Про доступ до публічної інформації: Закон України від 13.01.2011 р. № 2939-VI. Дата оновлення: 01.05.2015. URL: https://zakon.rada.gov.ua/ laws/show/2939-17 (дата звернення: 21.06.2019).

5. Про звернення громадян: Закон України від 02.10.1996 р. № 393/96-ВР. URL: https://zakon2.rada.gov.ua/laws/show/393/96-\%D0\%B2\%D1\%80 (дата звернення: 21.06.2019).

6. Завдяки судовій реформі довіра українців до судів зросла у чотири рази. Опитування. URL: https://www.ukrinform.ua/rubric-society/2566858-zavdaki-sudovijreformi-dovira-ukrainciv-do-sudiv-zrosla-u-cotiri-razi.html (дата звернення: 01.07.2019).

7. Кравчук В. М., Кравчук В.М. Громадський контроль судової влади як спосіб відновлення довіри суспільства до судів та суддів. Актуальні проблеми правознавства. 2016. Вип. 3. С. 11-16.

8. Бутко К., Куйбіда Р., Маселко Р., Середа М., Смалюк Р., Чижик Г. Кваліфікаційне оцінювання суддів: 2016-2018: проміжні результати. URL: https://drive.google.com/file/d/0B6uL2q_P82_80UI1Nko1MmFHM2FVU19vV0I2RzhjMFZr SDJV/view (дата звернення: 11.07.2019).

9. Про забезпечення права на справедливий суд: Закон України від 12.02.2015 p. № 192-VIII. URL: https://zakon4.rada.gov.ua/laws/show/192-19/page (дата звернення: 21.06.2019).

\section{References}

1. Pro informaciyu: Zakon Ukrayini vid 02.10.1992 r. № 2657-XII. Data onovlennya: 01.01.2017. URL: https://zakon.rada.gov.ua/laws/show/2657-12 (accessed: 11.06.2019) [in Ukrainian].

2. Pro zatverdzhennya Polozhennya pro nabori danih, yaki pidlyagayut oprilyudnennyu $\mathrm{u}$ formi vidkritih danih: postanova Kabinetu Ministriv Ukrayini vid 21.10.2015 r. № 835. URL: https://zakon.rada.gov.ua/laws/show/835-2015-\%D0\%BF\#n12 (accessed: 11.06.2019) [in Ukrainian].

3. Pro zapobigannya korupciyi: Zakon Ukrayini vid 14.10.2014 r. № 1700-VII. URL: https://zakon.rada.gov.ua/laws/show/1700-18 (accessed: 11.06.2019) [in Ukrainian].

4. Pro dostup do publichnoyi informaciyi: Zakon Ukrayini vid 13.01.2011 r. № 2939-VI. Data onovlennya: 01.05.2015. URL: https://zakon.rada.gov.ua/laws/show/293917 (accessed: 21.06.2019) [in Ukrainian].

5. Pro zvernennya gromadyan: Zakon Ukrayini vid 02.10.1996 r. № 393/96-VR. URL: https://zakon2.rada.gov.ua/laws/show/393/96-\%D0\%B2\%D1\%80 (accessed: 21.06.2019) [in Ukrainian].

6. Zavdyaki sudovij reformi dovira ukrayinciv do sudiv zrosla u chotiri razi. Opituvannya. URL: https://www.ukrinform.ua/rubric-society/2566858-zavdaki-sudovijreformi-dovira-ukrainciv-do-sudiv-zrosla-u-cotiri-razi.html (accessed: 01.07.2019) [in Ukrainian].

7. Kravchuk, V. M., Kravchuk, V.M. (2016). Gromadskij kontrol sudovoyi vladi yak sposib vidnovlennya doviri suspilstva do sudiv ta suddiv. Aktualni problemi pravoznavstva, 3, 11-16 [in Ukrainian].

8. Butko K., Kujbida R., Maselko R., Sereda M., Smalyuk R., Chizhik G. Kvalifikacijne ocinyuvannya suddiv: 2016-2018: promizhni rezultati. URL: https://drive.google.com/ file/d/0B6uL2q_P82_80UI1Nko1MmFHM2FVU19vV0I2RzhjMFZrSDJV/view (accessed: 11.07.2019) [in Ukrainian]. 
9. Pro zabezpechennya prava na spravedlivij sud: Zakon Ukrayini vid $12.02 .2015 \mathrm{r}$. № 192-VIII. URL: https://zakon4.rada.gov.ua/laws/show/192-19/page (accessed: 21.06.2019) [in Ukrainian].

N. Nestor, PhD in Law, Candidate for Doctor of Law of Open International University of Human Development «Ukraine»

\section{System of administrative measures of public control of judges in Ukraine}

The article describes the system of various ways of carrying out administrative control procedures by civil society entities, in particular through such forms as monitoring (observation, analysis) and examination. It is noted that quite often the same method of control can correspond to multiple administrative procedures for its implementation. The author argues that in relation to other forms (verification, evaluation, correction of the personnel of the judicial corps, bodies of judicial administration and judicial self-government, leadership of the court and the State Judicial Administration of Ukraine, rulemaking), they are not peculiar to the administrative and legal status of subjects of public control.

It is established that the system of various ways of carrying out administrative control procedures within its forms (observation, analysis), expertise is a set of measures: 1) obtaining information from open or closed sources, by the results of sociological research, personal interviews (conversations, consultations) with third parties (including those subject to scrutiny), journalistic investigations, etc.; 2) intelligent, mental processing of the information received, including through innovative technologies and computer algorithms, with the formation of their own conclusions, reports, reviews, and other forms of expression of the results of analytical or expert work; 3 ) forwarding information (conclusions, materials) by any interested entity to the High Council of Justice within the framework of the disciplinary complaint procedure; 4) submission of a negative opinion by the Public Council of Integrity regarding the compliance of the judge (candidate for this position) with the requirements of professional ethics and integrity of the High Qualifications Commission of Judges; 5) creation and maintenance of specialized Internet sites that simplify (make more convenient and understandable) public access to relevant information about the court and judges; 6) publication of the results of analytical and expert work (consolidated information with conclusions, comments of interested parties in the media, in particular on television and on the Internet.

Keywords: public control; court; judge; judicial sphere; public.

Надійшла до редакції 14.07.2019 